\title{
Is Oreochromis niloticus invading the Samborombón Bay, Río de la Plata, Argentina?
}

\author{
Mirta L. GARCÍA ${ }^{1,2}$, Mariela CUELLO ${ }^{1,2}$, Agustín SOLARI ${ }^{1,2}$, Andrés C. MILESSI ${ }^{3,4}$, \\ Federico CORTÉS ${ }^{2,4}$, Ignacio M. BRUNO ${ }^{5} \&$ María F. ZAPATA $^{5}$
}

\begin{abstract}
${ }^{1}$ Facultad de Ciencias Naturales y Museo. Universidad Nacional de la Plata. Paseo del Bosque s/n 1900 La Plata, Argentina.mlgarcia@fcnym.unlp.edu.ar. ${ }^{2}$ Consejo Nacional de Investigaciones Científicas y Técnicas (CONICET), Buenos Aires, Argentina. ${ }^{3}$ Comisión de Investigaciones Científicas de la Provincia de Buenos Aires (CIC), Argentina. ${ }^{4}$ Instituto Nacional de Investigación y Desarrollo Pesquero, Mar del Plata, Argentina (INIDEP), Paseo Victoria Ocampo No. 1, 7600 Mar del Plata, Argentina. ${ }^{5}$ Fundación Aquamarina/CECIM. Programa Regional de Investigación y Conservación de Tortugas Marinas de Argentina
\end{abstract}

\begin{abstract}
The Nile tilapia (Oreochromis niloticus) is a species widely cultivated worldwide. In recent decades it was an increasing development of fish farming of this species and the red variety in Argentina and Uruguay. From January to March 2010, four specimens of O. niloticus were captured in the south boundary of Samborombón Bay ( $\mathrm{S} 36^{\circ} 17^{\prime}-\mathrm{W} 56^{\circ} 46^{\prime}$ ), which is the external sector of the Río de la Plata. Probably the collected specimens were released accidentally from hatcheries placed on the banks of aquatic environments in communication with the Samborombón Bay. The patterns and mechanisms of species dispersal are of significant interest, while the interactions among factors determining invasion success often remain poorly understood. Invasion success is influenced by the ability of invading specie to withstand, interactions with native species and oceanographic characteristics of the new habitat. Of four specimens obtained two were females, one in spawning stage. This is the first record of Nile tilapia from a natural environment in Argentina and could indicate the beginning of a new invasion by a non native species.
\end{abstract}

Key words: Oreochromis niloticus, First record, exotic species, Río de la Plata.

Resumen: ¿Es Oreochromis niloticus un invasor en la Bahía de Samborombón, Río de la Plata (Argentina)? La Tilapia del Nilo (Oreochromis niloticus) es una especies cultivada en todo el mundo. En Argentina y Uruguay, la cría de tilapia ha tenido un incremento importante en las últimas décadas. Entre enero y marzo de

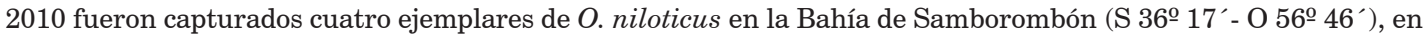
el sector externo del Río de la Plata. Probablemente los ejemplares capturados puedan haber resultado de escapes accidentales de criaderos ubicados en ambientes en comunicación con el Río de la Plata. De los cuatro ejemplares capturados dos fueron hembras, una de ellas en etapa de desove. Este es el primer registro de Tilapia del Nilo en un ambiente natural en Argentina y podría indicar el comienzo de una invasión por una especie no nativa. Los patrones y los mecanismos de dispersión de especies son de gran interés, mientras que las interacciones entre los factores que determinan el éxito de la invasión a menudo, son poco interpretadas. El éxito de la invasión está influenciado por la capacidad de los invasores para resistir a las interacciones con especies nativas y con las características oceanográficas del nuevo hábitat, que en este caso parecerían no ser desfavorables para O. niloticus.

Palabras clave: Oreochromis niloticus, primer registro, especie exótica, Río de la Plata.

\section{INTRODUCTION}

The tilapiine fishes are originally an exclusively African group of species (Trewavas, 1983; Pullin, 1988). They have been introduced in different parts of the world for biocontrol of aquatic weeds and insects for improve or to develop aquaculture fisheries. A huge amount of information is available on this group, which has received as much attention in the tropics as salmonids in temperate areas. Today, the tilapiine fishes are likely the world most distributed exotic fish species, having established in every tropical and subtropical environment to which they have gained access (Costa-Pierce, 2003).

The African Nile tilapia, Oreochromis niloticus (Linnaeus, 1758) is a cichlid fish native to the large lakes and rivers of Africa. This species is the best for aquaculture, due to its wide resistance to environmental factors and their well-known ma- 
nagement (Welcomme, 1988). It is an omnivorous species with parental care and territorial habits. After the common carp (Cyprinus carpio), the tilapia is the freshwater fish species with a high production by world aquaculture, with excellent markets and sustained demand. Its cultivation is widespread in Asia and Latin America (Dirección Nacional de Pesca y Acuicultura, DNPA, 2003; De Silva et al., 2004). Particularly in Argentina, the Nile tilapia was introduced in the North of the country (Misiones province) at the end of 1930 , and later other imports were made in 1950, 1980 and 1990. All these introductions and transfers were without legal authorization of the DNPA, in certain cases because there was no yet official control and in others because they were illegal introductions. More recently, the DNPA authorized the introduction of the red hybrid nilotica in the Misiones province and $O$. niloticus in the Corrientes province. There are other projects in the provinces of Formosa, Chaco, Santa Fe, Entre Ríos and Buenos Aires. Farming has been also developed at Lavalleja and Salto departments in Uruguay. All these places are located in the Paranoplatense Basin (DNPA, 2003; DINARA-FAO, 2008).

In this paper, we report for the first time the presence of O. niloticus in the Samborombón Bay, a main mixohaline environment in the same basin where cultivation of this species is carried on.

\section{MATERIAL AND METHODS}

From January to March 2010 four specimens of $O$. niloticus were captured with a 80 to 110 $\mathrm{mm}$ stretched mesh size bottom-fixed gill-net positioned for up to $12 \mathrm{hs}$ of fishing in the south boundary of Samborombón Bay (S $36^{\circ} 17^{\prime}$ - W $56^{\circ}$ $\left.46^{\prime}\right)$ at the external sector of the Río de la Plata (Fig. 1). Measurements (mm), body weights (gra$\mathrm{ms}$ ) are included and sex and maturity stage were determined. Three specimens were deposited in the Ichthyological Collection of the Museo de La Plata, MLP 9770.

The monthly Sea Surface Temperature (SST) data (precision $1^{\circ}$ latitude $\times 1^{\circ}$ longitude) from January 1982 to February 2010 were taken from http://podaac.jpl.nasa.gov/poet (Reynolds \& Smith, 1994; Reynolds et al., 2002). Then, the monthly average SST anomalies $(\Delta \mathrm{SST})$ were determined for the study area (S $36^{\circ}-37^{\circ}$ and $\mathrm{W}$ $56^{\circ}-57^{\circ}$ ) based on the long-term monthly average (1982 to 2010).

\section{RESULTS AND DISCUSSION}

The specimens caught measured $600,580,450$ and $290 \mathrm{~mm}$ in total length and 4,900, 4,010, 2,350

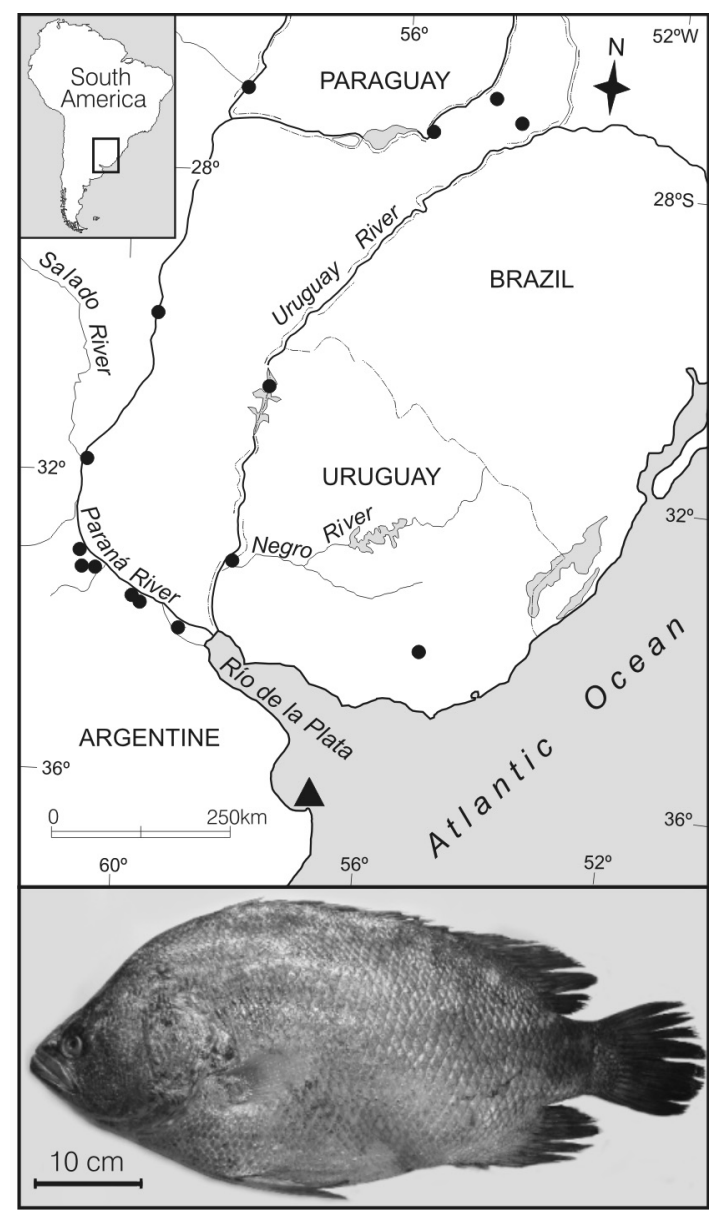

Fig. 1. $\Delta$ ) First record of Oreochromis niloticus in the Samborombón Bay ( $\left.36^{\circ} 17^{\prime} \mathrm{S}-\mathrm{W} 36^{\circ} 46^{\prime}\right)$, •) aquaculture fisheries of $O$. niloticus in the Paranoplatense Basin.

and $490 \mathrm{~g}$ respectively. The last two specimens were females, one in spawning stage.

The analysis of the average monthly $\Delta$ SST time series shows a warm period (positive $\Delta$ SST) in the study area from November to April with a maximum of $6.07^{\circ} \mathrm{C}$ in February and a cold period (negative $\triangle \mathrm{SST}$ ) from May to October, with a lowest value off $-5.89^{\circ} \mathrm{C}$ (Fig. 2). The most elevated monthly average $\Delta \mathrm{SST}\left(8.37^{\circ} \mathrm{C}\right)$ was observed in February 2010, which is consistent with the occurrence of the species in the study area.

In spite of introductions in Argentina, intensive production performed by Brazil for several decades and culture by Paraguay, and considering the wide connections among watersheds, apparently the tilapia did not established in the Paranoplatense basin. This suggests that in these environments could be limiting physical and che- 


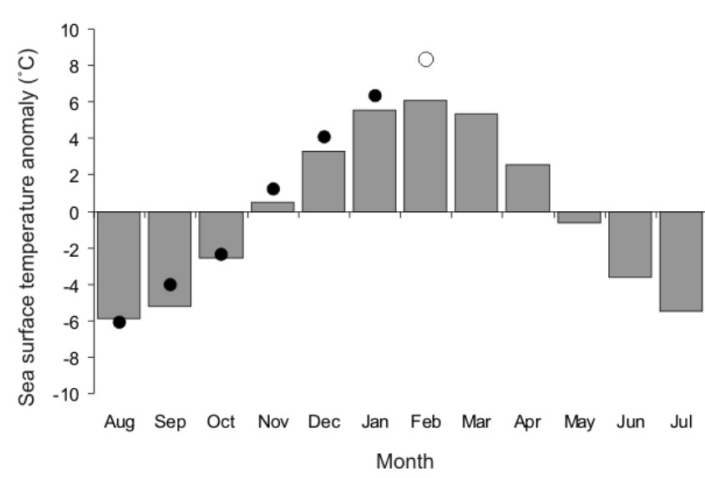

Fig. 2. Long-term monthly average sea surface temperature anomalies $(\Delta \mathrm{SST}) . \bullet) \Delta \mathrm{SST}$ from August 2009 to January 2010. o) $\Delta$ SST in February 2010.

mical parameters for settlement and sustainability of tilapia (DNPA, 2003).

However, it is proved that tilapia is a very resistant species and is able to survive in extreme environmental conditions, such as high temperatures (up to $43^{\circ} \mathrm{C}$; Bezault et al., 2007), high salinity (up to $57 \mathrm{ppm}$; Mateo et al., 2004), and elevated concentrations of toxicants (El-Shafai $e t$ al., 2003; García-Santo et al., 2006). All of these factors explain its success, sometimes invasive establishment in critical or polluted environmental conditions (Khallaf et al., 2003), although it is sensitive to cold waters. In the subtropical region temperature would be a limiting factor to the development of the species, because the lowest lethal thermal limit is between 9.6 and $13.6^{\circ} \mathrm{C}$, depending on the environmental conditions and genetic origin of the fish stock (Charo-Karisa et al., 2005). However, the species shows an adaptive selection to low temperatures (Peterson et $a l ., 2005)$. Tilapia also can adapt to live, play and have a viable offspring in the marine environment, condition that has been exploited to cultivate at sea (Watanabe, 1991). Tilapia hybrids also resist high salinity (Mateo et al., 2004). These traits probably facilitate the colonization and development of the species in areas as the Samborombón Bay, where ranges of water temperature and salinity are between 11.3 and $21.7^{\circ} \mathrm{C}$ and 15.09 and 21.3 , respectively (Guerrero et al., 2004).

Often introductions have not been preceded by scientific studies of the biotic and abiotic conditions, so expected objectives were not achieved and at the same time, escape of fishes to other environments have caused a dangerous decrease in numerous aquatic species (Arratia, 1978). This situation occurred with the introduction of tilapia in several countries of the world. For example, the introduction of $O$. mossambicus, $O$. niloticus and $O$. spp in Venezuela has been the main cause of the extinction of the autochthonous atherínid Atherinella venezuelae (Infante, 1985, Solórzano et al., 2001). This country also lost more than $50 \%$ of its diversity (from 23 to 10 species) after 12 years of the introduction of tilapia (Carvajal, 1965). Tilapia also surpassed the lagoon and populated some rivers and colonizes nearby marine environments. In some rivers of Colombia the tilapia displaced Prochilodus magdalenae (Aguilera \& Carvajal, 1976).

The FAO (1997) noted that in aquatic environment fishes easily exceed the limits of installations devoted to its cultivation. Therefore, the introduction of organisms for aquaculture activities should be considered a deliberate introduction in the natural space, even if the quarantine centre or the farm may be a closed system. It is necessary to emphasize that invading exotic species that do not find predators and natural parasites in the new environment may widely expanse their population. For these reasons and the risks involved in the cultivation of tilapia due to the possibility of some casual escapes from the sites of cultivation to the natural environment, organizations such as the International Council for the Exploration of the seas, the Environmental Protection Agency and the Fish and Wildlife Service have proposed several codes of procedure management to mitigate the devastating effects of these introductions (TED, 2001).

This record for the Río de la Plata is the first of this species in a natural brackish (estuarial) environment in Argentina. The perfect conditions of the specimens indicate that we would face possible disruption by an invasive species that has already caused the extinction of several autochthonous species in many countries. It would be necessary to investigate the trophic ecology of $O$. niloticus to determine the interaction with native species in this environment and the changes that it may cause in the structure of the ecosystem. The DNPA (2003) has already indicated that farming should also be carried on with selected reverse sex lines.

\section{ACKNOWLEDGEMENT}

Special thanks to Dr. R. Menni for the critical reading of the manuscript and the local fishermen for their field work support and friendship.

\section{BIBLIOGRAPHY}

Aguilera, L. \& J. Carvajal. 1976. La ictiofauna del complejo hidrográfico Río Manzanares, Estado Sucre, Venezuela. Lagena 37-38: 23-25. 
Arratia, G. 1978. Comentario sobre la introducción de peces exóticos en aguas continentales de Chile. Cs. Forest. 1: 21-30.

Bezault, E., F. Clota, M. Derivaz, B. Chevassus \& J.F. Baroiller. 2007. Sex determination and temperature-induced sex differentiation in three natural populations of Nile tilapia (Oreochromis niloticus) adapted to extreme temperature conditions. Aquaculture 272: S3-S16.

Carvajal, L. 1965. Estudio ecológico de las lagunas litorales vecinas a la ciudad de Cumaná. Bol. Inst. Oceanog. Venezuela 4 (42): 266-311.

Costa-Pierce, B.A. 2003. Rapid evolution of an established feral tilapia (Oreochromis spp.): the need to incorporate invasion science into regulatory structures. Biol. Invasions 5: 71-84.

Charo-Karisa, H., A.R. Mahmoud, H. Bovenhuis \& H. Komen. 2005. Heritability of cold tolerance in Nile tilapia Oreochromis niloticus juveniles. Aquaculture 249: 115-123.

De Silva S.S., R.P. Subasinghe, D.M. Bartley \& A. Lowther. 2004. Tilapias as alien aquatics in Asia and the Pacific: a review. FAO Fisher. Tech. Paper 453, Rome, Italy, $65 \mathrm{pp}$.

DINARA-FAO. 2008. Uruguay. Plan Nacional de desarrollo de la acuicultura. Polít. Nac. Desar. Acuic. Sost. Rep. Orient. Urug, Montevideo. www.dinara. gub.uy/web_dinara/images/stories/publicaciones/ politic_acui_sostenible.pdf

Dirección Nacional de Pesca y Acuicultura. 2003. Acerca de la introducción de las especies de "tilapias" en argentina y antecedentes de su cultivo $y$ comercialización, en otros países del área latinoamericana. Dir. Acuic., Buenos Aires. http://www.sagpya.mecon.gov.ar/new/0-0/pesca/acuicultura/cultivo/Introducci\% F3n\%20Tilapia

El-Shafai, S.A., F.A. El-Gohary, F.A. Nasr, N.P. van der Steen \& H.I. Gijzen. 2003. Chronic ammonia toxicity to duckweed-fed tilapia (Oreochromis niloticus). Aquaculture 232: 117-127.

FAO. 1997. Review of the state of world aquaculture. FAO Fish. Circ. № 886 Rev. 1. InlandWater Resources and Aquaculture Service, Fish. Res. Div., Rome, Italy, 163 pp.

García-Santo, S., A. Fontaínhas-Fernandes \& J.M. Wilson. 2006. Cadmium tolerance in the Nile tilapia (Oreochromis niloticus), following acute exposure: assessment of some iono-regulatory parameters. Environ. Toxicol. 21: 33-46.

Guerrero, R.A., G.N. Molinari, S.I. Jauregui, A.R. Piola \& A.P. Osiroff. 2004. Análisis de datos oceanográficos históricos. Informe del Proyecto Protección ambiental del Río de la Plata y su Frente Marítimo: prevención y control de la conta- minación y restauración de hábitats. PNUD/GEF, RLA/99/G31. www.freplata.org/documentos/archivos/DOCUMENTOS_FREPLATA/DATOS_historicos/TS Historicos.PDF

Infante, O. 1985. Aspectos bioecológicos de la tilapia Sarotherodon mossambicus (Peters 1852, Teleostei, Perciformes, Cichlidae) en el lago de Valencia, Venezuela. Acta Cient. Venezol. 36: 68-76.

Khallaf, E.A., M. Galal \& M. Authman. 2003. The biology of Oreochromis niloticus in a polluted canal. Ecotoxicology 12: 405-416.

Mateo, D., R. Aguilar, W. Campos, M.S. Katalbas, R. Sanares, R. Edra, B. Chevassus, J. Lazard, P. Morisens, J.F. Baroiller \& X. Rogñon. 2004. Salinity tolerance of Oreochromis niloticus and O. mossambicus $\mathrm{F} 1$ hybrids and their successive backcross. En: R.B. Bolivar, D.A. Mair \& K.F. Fitzsimonis (Eds): Proceeding 6th International Symposium on tilapia in aquaculture. pp. 123-136, Manila.

Peterson, M.S., W.T. Slack \& C.M. Woodley. 2005. The occurrence of non-indigenous Nile tilapia, Oreochromis niloticus (Linnaeus), in coastal Mississippi, USA: Ties to aquaculture and thermal effluent. Wetlands 25: 112-121.

Pullin, R.S.V. 1988. Tilapia Genetic Resources for Aquaculture. ICLARM Conference Proceedings 16, International Center for Living Aquatic Resource Management. pp 118, Manila

Reynolds, R.W. \& T.M. Smith.1994. Improved global sea surface temperature analyses using optimum interpolation. J. Climate 7: 929-948.

Reynolds, R.W., N.A. Rayner, T.M. Smith, D.C. Stokes \& W. Wang. 2002. An improved in situ and satellite SST analysis for climate. J. Climate 15: 1609-1625.

Solórzano, E., C. Marcano-Chirguita, A. Quijada \& M. Campo. 2001. Impacto ecosistémico de las tilapias introducidas en Venezuela. En J. Ojasti, E. González-Jiménez, E. Szeplaki-Otahola \& L.B. García-Román (Eds): Informe sobre las especies exóticas en Venezuela. pp. 194-199, Tipodin, Caracas.

TED (Trade and Environment Database). 2001. Tilapia and the environment. http://www.american.edu/ ted/TILAPIA.HTM.

Trewavas, E. 1983. Tilapiine Fishes of the Genera Sarotherodon, Oreochromis and Danakilia. British Mus Nat Hist, London, 533 pp.

Watanabe, W.O. 1991. Saltwater culture of tilapia in the Caribbean. World Aquacul. 22: 49-54.

Welcomme, R.L. 1988. International introductions of inland aquatic species. FAO Fish. Tech. Paper 294, Rome, Italy, 318pp.

Recibido: 23-VI-2010

Aceptado: 20-XII-2010 